Article

\title{
RELATIONSHIP BETWEEN INTERNAL MORPHOLOGY AND PHYSIOLOGICAL QUALITY OF Leucaena leucocephala SEEDS USING IMAGE ANALYSIS
}

André Dantas de Medeiros ${ }^{2 *} \odot$, Manuel Jesús Zavala-León ${ }^{3} \odot$, Joyce de Oliveira Araújo ${ }^{2} \odot$, Márcio Dias Pereira ${ }^{4}$, Denise Cunha Fernandes dos Santos $\operatorname{Dias}^{2}+$ and Laércio Junio Silva² ${ }^{\circ}$

${ }^{1}$ Received on 25.09.2018 accepted for publication on 09.08.2019.

${ }^{2}$ Universidade Federal de Viçosa, Departamento de Fitotecnia, Viçosa,MG - Brasil. E-mail: <medeiros.seeds@gmail.com>, <dcunhadias@gmail. com> and <joycearaujo.agro@gmail.com>,<laerciojdsilva@gmail.com>.

${ }^{3}$ Instituto Nacional de Investigaciones Forestales, Agrícolas y Pecuarias/INIFAP, Ciudad de México, México. E-mail: <manuel_zavala52@hotmail. com>.

${ }^{4}$ Universidade Federal do Rio Grande do Norte, Escola Agrícola de Jundiaí, Macaíba,RN - Brasil. E-mail: <marcioagron@yahoo.com.br>.

*Corresponding author.

ABSTRACT - The use of new methodological approaches and inclusion of non-destructive evaluations in determining the quality of forest seeds has proven to be of great importance for the development of forest production. The aim of this study was to evaluate the effectiveness of the use of a semi-automated tool for measurement of digital images obtained by the X-ray test in seed lots of Leucaena leucocephala and their relationship to seed physiological quality. Seeds were collected from five mother trees in Viçosa, MG. The study was performed through analysis of radiographic images of the seeds. It was determined the percentage of damaged seeds (predation and fungi) and measured: the area, perimeter, circularity, relative density, and integrated density of the seeds. After the X-ray test, a germination test was performed on the seeds, from which ten variables related to seed physiological quality were extracted, including a vigor index. The use of semi-automated measurement tools associated with the X-ray test was effective for evaluating the internal morphology of Leucaena leucocephala seeds, and the variables determined are related to seed physiological quality.

Keywords: ImageJ; Relative density; Radiography

\section{RELAÇÃO ENTRE MORFOLOGIA INTERNA E QUALIDADE FISIOLÓGICA DE SEMENTES DE Leucaena leucocephala USANDO ANÁLISE DE IMAGENS}

RESUMO-Ouso de novas abordagens metodológicas e a inclusão de avaliações não destrutíveis na determinação de qualidade das sementes florestais tem se mostrado de grande importância para o desenvolvimento da produção florestal. O objetivo deste trabalho foi avaliar a eficácia do uso de ferramenta semi-automatizada de medição de imagens digitais obtidas no teste de raios X em lotes de sementes de Leucaena leucocephala e sua relação com a qualidade fisiológica das sementes. Para tanto, foram utilizadas sementes de cinco lotes colhidos de árvores-matrizes localizadas na região de Viçosa, $M G$. O estudo foi realizado por meio da análise de imagens radiográficas das sementes, para as quais foram obtidos o percentual de sementes com danos (predação efungos), e medidas de área, perímetro, circularidade, densidade relativa e densidade integrada das sementes. Após o teste de raios $X$, as sementes foram submetidas ao teste de germinação, em que se extraíram dez variáveis relacionadas à qualidade fisiológica das sementes, dentre elas um índice de vigor. $O$ uso de ferramentas de medição semiautomatizada associado ao teste de raios Xé eficaz para avaliar a morfologia interna das sementes de Leucaena leucocephala e suas variáveis apresentam relação com a qualidade fisiológica das sementes.

Palavras-chave: ImageJ; Densidade relativa; Radiografia

Silf $(c))$ EY
Revista Árvore 2019;43(2):e430208

http://dx.doi.org/10.1590/1806-90882019000200008 


\section{INTRODUCTION}

Leucaena leucocephala is a tree species widely distributed throughout Brazil. It is naturally resistant to most biotic and abiotic stresses (Honda et al., 2018) and has important ecological value because it contributes to improvement of the soil upon fixing nitrogen and controlling erosion in arid regions (Yige et al., 2012). Given these advantages and uses, it is normally included among the species that are to compose agroforestry systems (Pereyra et al., 2015), and this has increased demand for quality seeds of this species.

The difficulty of obtaining seeds with physical and physiological quality is one of the factors that most limit commercial production of forest seeds, and consequently, most seeds sold are still of low quality. The main tests that evaluate seed quality are described by the Rules for Seed Analysis (Brasil, 2009) and vigor manuals of the Brazilian Seed Technology Association [Associação Brasileira de Tecnologia de Sementes] (Krzyananowski et al., 1999). However, most of these analyses are time consuming and destructive, which can be considered expensive in the seed trade, involving production and sale of seeds and, after that, seedling production (Noronha et al., 2018).

Therefore, the development of non-destructive methods that allow quick evaluation of seed quality can effectively contribute to decision making regarding the use or discard of seed lots (Marchi and Cicero, 2017). One of the methods reported as promising for this purpose is use of the X-ray technique.

This technique is based on absorption of $\mathrm{X}$-rays by seed tissues, which is determined by the factors of composition, thickness, tissue density, and wavelength of the ionizing radiation (Brasil, 2009). The radiography acquired is characterized by different gray tones (Prado et al., 2018). Since it is a non-destructive and quick method for seed analysis, it can be integrated with other laboratory tests, saving time and resources.

Variables such as percentage of filling of the internal seed cavity (Silva et al., 2013; Noronha et al., 2018), embryo size (Marchi and Gomes Junior, 2017), and identification of full seeds and of embryonic abnormality (Gomes et al., 2014) are usually used in X-ray studies with seeds from forest species, together with analysis of their physiological quality. However, radiographic images are open to subjective interpretation. Thus, there is the recurring need for automation of these determinations (Abud et al., 2018).

Given this situation, variables such as size, pixel density, shape, texture, and other descriptors measured by software allow elimination of subjectivity in analysis and can constitute indicators of physical quality, along with the physiological potential of the seeds. The free Image $₫$ software is an alternative for this type of determination (Schneider et al., 2012) and has shown potential for radiographic image analysis of seeds. For broccoli (Abud et al., 2018) and moringa (Noronha et al., 2018) seeds, efficient use of this software for evaluation of the internal morphology of seeds has demonstrated the practical application of the technique.

Considering the importance of more efficient methodological approaches in determination of seed quality, the aim of this study was to evaluate the effectiveness of using a semi-automated tool for measurement of digital images obtained by the X-ray test in Leucaena leucocephala seeds and their relationship to the physiological quality of the seeds.

\section{MATERIALS AND METHODS}

The experiment was conducted in the Laboratory of Seed Analysis of the Plant Science Department of the Universidade Federal de Viçosa, Viçosa, Minas Gerais, Brazil. Five lots of Leucaena leucocephala seeds harvested from ripe fruit from the mid-region of the canopy of ten mother trees in a forested area in the municipality of Viçosa were used.

Initially, seeds from each lot were tested for moisture content by the laboratory oven method at 105 $\pm 3{ }^{\circ} \mathrm{C}$ for 24 hours (Brasil, 2009); two replications of 20 seeds for each lot were used for this purpose.

For analyses of internal seed morphology, four replications of 50 seeds from each lot were used. The method proposed by Abud et al. (2018) was used, which consisted of placing the seeds on transparency paper with double-sided tape to attach the seeds in a determined order, allowing individual identification in subsequent analyses. After that, radiographic images were generated using the Faxiton equipment, model

Revista Árvore 2019;43(2):e430208 
MX-20 DC-12, connected to a Core 2 Duo computer (3.16 GHz, 2 GB of RAM, hard disk of $160 \mathrm{~GB}$ ). Radiation of $32 \mathrm{kV}$ and a focal distance of $41.6 \mathrm{~cm}$ were used for 10 seconds. The images generated were stored on a computer and used for evaluation of percentage of seeds damaged by insects or fungi and seeds free of damage.

The images were also analyzed by the Image ${ }^{\circledR}$ software, which is a free semi-automated measurement tool, to obtain the following variables: area - area of selection obtained in square pixels and later converted into units of square millimeters $\left(\mathrm{mm}^{2}\right)$; perimeter - the length of the outer limit of selection; circularity - obtained from the equation $\mathrm{C}=4 \pi * \frac{\text { área }}{\text { (perímetro })^{2}}$, where values equal to 1.0 indicate a perfect circle and as values tend to 0 , they suggest an elongated shape; relative density (Geiger et al., 2016) - defined as the sum of gray values of all the pixels in the area selected, divided by the number of pixels of the selection; and integrated density - the sum of the values of the pixels in the image or selection, which is equivalent to the product of area and mean gray value (relative density).

After the X-ray test was performed, the seeds were manually scarified, sanding the tip opposite the embryonic axis enough to allow water to enter the seed so as to break seed dormancy caused by the seed coat (Brasil, 2009). Then the germination test was performed on the seeds, which was carried out in rolls of paper toweling moistened with water in the amount of 2.5 times the weight of the dry paper and kept in a seed germinator at $25^{\circ} \mathrm{C}$ (Brasil, 2009). In the germination paper, four replications of 50 seeds were used, maintaining the same arrangement of seeds originally used in the X-ray test. The final count of germination was performed on the tenth day after sowing (Brasil, 2009), at which time the percentage of germinated seeds (radicle emergence $>5 \mathrm{~mm}$ ) and of normal seedlings were obtained.

Seedling length was obtained with a ruler in millimeters, and for each replication, the growth, uniformity, and vigor indices were generated from equations proposed by Sako et al. (2001), as well as the corrected vigor index proposed by Medeiros and Pereira (2018), obtained by the following equation: $\mathrm{CVI}=(0.7 * \mathrm{GI}+0.3 * \mathrm{UI}) * \frac{* \text { Gemination }(\%)}{100}$, where CVI $=$ corrected vigor index; GI = growth index; and UI = uniformity index. The length results were expressed in millimeters per seedling and the indices in adimensional values, ranging from 1 to 1000 ; the higher the value, the better the performance for that trait.

To determine seedling dry matter, the cotyledons were removed with the aid of a scalpel, and the seedlings were placed in paper bags and then in an air circulation laboratory oven to dry at $65^{\circ} \mathrm{C}$ for 48 hours. After this period, the samples were removed from the laboratory oven, placed in a desiccator, and weighed. The weight of total dry matter of the seedlings from each replication was divided by the number of component seedlings, providing the dry matter weight per seedling, expressed in $\mathrm{g} /$ seedling (Nakagawa et al., 1999).

The experiment was conducted in a completely randomized experimental design. After confirming the normal distribution of errors by the Shapiro-Wilk test and homogeneity of variances by the Bartlett test, analysis of variance (ANOVA) was performed, and when a significant difference was detected, the mean values were compared by the Tukey test $(p \leq 0.05)$. After that, the Pearson simple correlation coefficients (r) were calculated for all the combinations between the tests of evaluation of seed physiological and physical quality, in which the significance of the $r$ values was determined by the test $(p \leq 0.05)$. The $\mathrm{R}$ software with the Exp.Des package (R Core Team, 2017) was used in statistical analyses.

\section{RESULTS}

\subsection{Characterization of seed physiological potential}

The moisture content of the seeds of the $L$. leucocephala lots at the time of setting up the experiment ranged from $8.1 \%$ to $8.8 \%$ (Table 1 ), which allowed visualization of the internal structures of the seeds.

Regarding seed physiological quality (Table 1), differences in germination (radicle emergence) and normal seedlings were identified between lots 1 and 3, and lot 3 had the lowest performance; however, it did not differ from lots 4 and 5 . The values ranged from 0.0099 to 0.0110 grams, but there were no significant differences among the lots.

\section{Revista Árvore 2019;43(2):e430208}

\section{silf}


Table 1 - Moisture content (MC), germination (G), normal seedlings (NS), seedling dry matter (SDM), hypocotyl length (HL), root length (RL), seedling length (SL) growth index (GI), uniformity index (UI), vigor index (VI), and corrected vigor index (CVI) of five seed lots of $L$. leucocephala.

Tabela 1 - Grau de umidade (MC), germinação (G), plântulas normais (NS), massa seca de plântulas (SDM), comprimento de hipocótilo $(H L)$, comprimento de raiz (RL), comprimento de plântula (SL), indice de crescimento (GI), indice de uniformidade (UI), indice de vigor (VI) e índice de vigor corrigido (CVI) de cinco lotes de sementes de L. leucocephala.

\begin{tabular}{cccccccccccc}
\hline Lot & $\begin{array}{c}\text { MC } \\
(\%)\end{array}$ & $\begin{array}{c}\text { G } \\
(\%)\end{array}$ & $\begin{array}{c}\text { NS } \\
(\%)\end{array}$ & $\begin{array}{c}\text { SDM } \\
(\mathrm{g})\end{array}$ & $\begin{array}{c}\mathrm{HL} \\
(\mathrm{mm})\end{array}$ & $\begin{array}{c}\text { RL } \\
(\mathrm{mm})\end{array}$ & $\begin{array}{c}\text { SL } \\
(\mathrm{mm})\end{array}$ & GI & UI & VI & CVI \\
\hline 1 & 8.1 & $100 \mathrm{a}$ & $98 \mathrm{a}$ & 0.0110 & $46 \mathrm{a}$ & $81 \mathrm{a}$ & $128 \mathrm{a}$ & $525 \mathrm{a}$ & $886 \mathrm{a}$ & $634 \mathrm{a}$ & $630 \mathrm{a}$ \\
2 & 8.4 & $96 \mathrm{a}$ & $96 \mathrm{a}$ & 0.0110 & $42 \mathrm{ab}$ & $77 \mathrm{ab}$ & $120 \mathrm{ab}$ & $493 \mathrm{ab}$ & $872 \mathrm{ab}$ & $607 \mathrm{ab}$ & $586 \mathrm{ab}$ \\
3 & 8.5 & $80 \mathrm{~b}$ & $78 \mathrm{~b}$ & 0.0103 & $35 \mathrm{c}$ & $57 \mathrm{c}$ & $92 \mathrm{c}$ & $374 \mathrm{c}$ & $790 \mathrm{c}$ & $499 \mathrm{c}$ & $402 \mathrm{~d}$ \\
4 & 8.5 & $90 \mathrm{ab}$ & $86 \mathrm{ab}$ & 0.0099 & $38 \mathrm{bc}$ & $59 \mathrm{c}$ & $98 \mathrm{c}$ & $394 \mathrm{c}$ & $820 \mathrm{c}$ & $521 \mathrm{c}$ & $468 \mathrm{~cd}$ \\
5 & 8.8 & $90 \mathrm{ab}$ & $90 \mathrm{ab}$ & 0.0107 & $40 \mathrm{abc}$ & $66 \mathrm{bc}$ & $106 \mathrm{bc}$ & $432 \mathrm{bc}$ & $832 \mathrm{bc}$ & $552 \mathrm{bc}$ & $505 \mathrm{bc}$ \\
\hline $\mathrm{F}$ & - & $4.96^{*}$ & $4.40^{*}$ & $3.08 \mathrm{~ns}$ & $8.43^{*}$ & $16.59^{*}$ & $17.34^{*}$ & $16.26^{*}$ & $15.21^{*}$ & $19.9^{*}$ & $14.94^{*}$ \\
$\mathrm{CV}(\%)$ & - & 7.18 & 8.48 & 5.26 & 7.41 & 7.74 & 6.58 & 7.19 & 2.39 & 4.52 & 9.12 \\
\hline
\end{tabular}

Lowercase letter indicates comparison within each column for each evaluation by the Tukey test $(\mathrm{p}<0.05)$; * $\mathrm{ns}=$ significant and non-significant by the $\mathrm{F}$ test $(\mathrm{p}<0.05) ; \mathrm{F}=\mathrm{F}$ test; $\mathrm{CV}=$ coefficient of variation.

Letra minúscula indica comparação dentro de cada coluna para cada avaliação pelo teste de Tukey ( $p<0,05) ;{ }^{*}$, ns $=$ significativo e não significativo pelo teste $F(p<0,05)$; Teste $F=F ; C V=$ coeficiente de variação

In the measures of seedling length, significant differences were detected among the lots. In general, lots 1 and 2 were superior; lot 5 had an intermediate response; and lots 3 and 4 had the lowest performance.

The indices obtained from seedling analyses also identified differences in physiological potential among the lots, ranking them in three levels, such that lot 1 and 2 (high vigor) differed from lots 3 and 4 (low vigor), while lot 5 had an intermediate response, differing only from lot 1 .

\subsection{Identification of seed damage}

The images obtained by the X-ray test allowed identification of essential structures of the $L$. leucocephala seeds, such as the embryo, cotyledons, and seed coat (Figure 1A). In addition, they allowed observation of damages from tissue deterioration, possibly caused by the presence of fungi in the seed (Figure $1 \mathrm{~B}$ and 1E), and damage from insects (Figure $1 \mathrm{C}, 1 \mathrm{D}$, and $1 \mathrm{~F})$.

Regarding the occurrence of damage from insects and fungi and absence of damage in L. leucocephala seeds, lots 1 and 2 had physical quality that was statistically different and superior to lots 3 and 4 , although they did not have statistical differences in relation to lot 5 (Table 2).

Lots 1 and 2 had a lower occurrence of insect and fungus attacks, resulting in a higher percentage of seeds without damage; the mean values among these lots varied by $0.5 \%-97 \%$ for lot 1 and $96.5 \%$

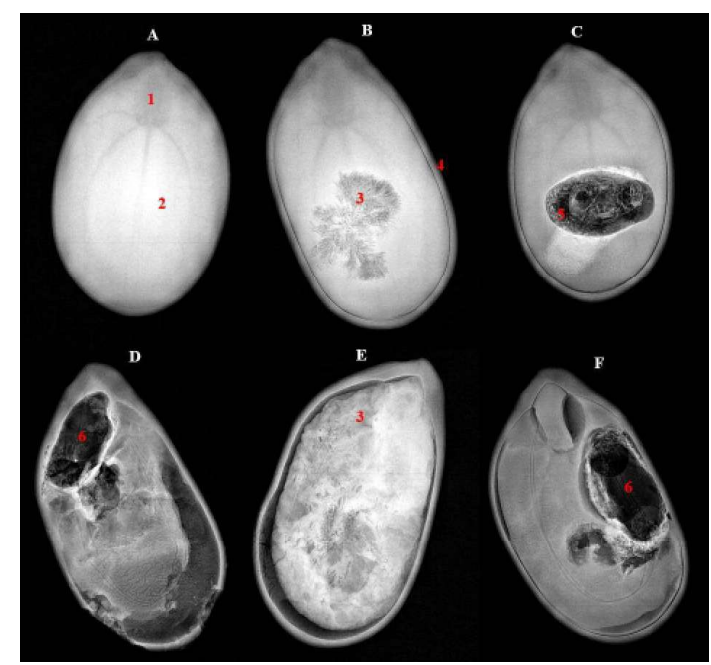

Figure 1 - Seeds without embryo damage (A); seeds with damage due to tissue deterioration (B); seed with insect lodged inside (C); dead seed (D); seed at an advanced stage of tissue deterioration (E); seeds with partially damaged axis and with symptom of predation (F). 1: embryonic axis; 2: cotyledons; 3 : region in deterioration, attacked by fungus; 4: seed coat; 5 : insect; 6: insect predation damage.

Figura 1 - Sementes sem danos ao embrião (A); sementes com danos por deterioração do tecido (B); sementes com insetos alojados no interior (C); semente morta (D); semente em estágio avançado de deterioração do tecido (E); sementes com eixo parcialmente danificado e com sintoma de predação (F). 1: eixo embrionário; 2: cotilédones; 3: região em deterioração, atacada por fungos; 4: tegumento da sementes; 5: inseto; 6: danos causados pela predação por insetos. 
for lot 2 (Table 2). In contrast, lots 3 and 4 had the highest incidence of damage, most commonly caused by insects, and these values were from $25 \%$ for lot 3 to $24.5 \%$ for lot 4 . Lot 5 had the highest incidence of fungi, and only lots 3 and 4 had more insect damage.

\subsection{Semi-automated analysis of the seed X-rays}

For the physical traits obtained from image analysis of the seeds from five L. leucocephala lots, there were no statistical differences for the variables of area, perimeter, and circularity(Table 3 ). Nevertheless, lots 1,2 , and 5 had greater relative density and integrated density, greater than the densities obtained by seeds from lots 3 and 4 .

From what was just mentioned above, it is clear that the seeds of the five lots had similar size

Table 2 - Incidence of damage in five L. leucocephala seed lots through analysis of digital X-ray images.

Tabela 2 - Incidencia de danos em cinco lotes de sementes de L. leucocephala através da análise de imagens de raios- $X$ digitais.

\begin{tabular}{cccc}
\hline & \multicolumn{3}{c}{ Damage \pm SEM } \\
\cline { 2 - 4 } Lot & Insect & Fungus & No damage \\
& ----------------- $\%$----------------- \\
\hline 1 & $1.5 \pm 0.27 \mathrm{~b}$ & $1.5 \pm 0.27 \mathrm{~b}$ & $97.0 \pm 0.16 \mathrm{a}$ \\
2 & $1.0 \pm 0.16 \mathrm{~b}$ & $2.5 \pm 0.27 \mathrm{~b}$ & $96.5 \pm 0.27 \mathrm{a}$ \\
3 & $25.0 \pm 1.27 \mathrm{a}$ & $1.0 \pm 0.16 \mathrm{~b}$ & $74.0 \pm 1.40 \mathrm{~b}$ \\
4 & $24.5 \pm 2.05 \mathrm{a}$ & $0.0 \pm 0.0 \mathrm{~b}$ & $75.5 \pm 2.05 \mathrm{~b}$ \\
5 & $4.5 \pm 0.90 \mathrm{~b}$ & $6.0 \pm 0.23 \mathrm{a}$ & $89.5 \pm 1.09 \mathrm{ab}$ \\
\hline $\mathrm{F}$ & $9.0 *$ & $9.3 *$ & $6.5 *$ \\
\hline
\end{tabular}

Mean values \pm standard error of the mean. Uppercase letter indicates comparison within each column for each evaluation by the Tukey test $(\mathrm{p}<0.05) ;{ }^{*}$, ns $=$ significant and non-significant by the $\mathrm{F}$ test $(\mathrm{p}<0.05)$.

Valores médios \pm erro padrão da média. Letra maiúscula indica comparação dentro de cada coluna para cada avaliação pelo teste de Tukey $(p<0,05) ; *$, ns = significativo e não significativo pelo teste $F(p<0,05)$. and shape (area, perimeter, and circularity), which was confirmed by the absence of significance in differences among values obtained for each lot. For their part, the relative density and integrated density allowed the five seed lots to be stratified in two groups. The first group was composed by lots 1,2 , and 5, which exhibited greater relative and integrated densities, and the second group was composed by lots 3 and 4 , which had lower densities.

\subsection{Pearson correlation}

Pearson correlation analysis indicated that the variables of area, perimeter, and circularity were not adequate for classification of the lots or to express a relationship with the variables of physiological quality used in this study (Table 4). In contrast, the variables related to tissue density (e.g. relative density and integrated density) had high correlation with the data of initial characterization.

\section{DISCUSSION}

\subsection{Characterization of seed physiological potential}

The low variation of moisture among the lots analyzed allowed comparison of physiological quality among them without this being compromised by the seed moisture factor (Marcos-Filho, 2016). Seed moisture is one of the factors that affect optical density in the X-ray (Simak, 1991). Therefore, seeds with low moisture content at the time of the X-ray test generate X-rays with greater detailing of the internal seed structures.

Germination of all the lots was greater than $65 \%$, the minimum value established for sale of seeds of

Table 3 - Area, perimeter, circularity, relative density, and integrated density obtained from analysis performed by ImageJ® software from radiographic images obtained in the X-ray test of five seed lots of Leucaena leucocephala.

Tabela 3 - Área, perímetro, circularidade, densidade relativa e densidade integrada obtidos da análise realizada pelo software ImageJ ${ }^{\circledR}$ a partir de imagens radiográficas obtidas no teste de raios-X de cinco lotes de sementes de Leucaena leucocephala.

\begin{tabular}{|c|c|c|c|c|c|}
\hline Lot & $\begin{array}{c}\text { Area } \\
\left(\mathrm{mm}^{2}\right)\end{array}$ & $\begin{array}{l}\text { Perimeter } \\
(\mathrm{mm})\end{array}$ & Circularity & $\begin{array}{l}\text { Relative density } \\
\text { (gray.pixel }{ }^{-1} \text { ) }\end{array}$ & $\begin{array}{l}\text { Integrated density } \\
\left(\text { gray.mm².pixel }{ }^{-1}\right)\end{array}$ \\
\hline 1 & 27.56 & 28.23 & 0.46 & $187.00 \mathrm{a}$ & $5154.82 \mathrm{a}$ \\
\hline 2 & 27.27 & 30.60 & 0.39 & $188.15 \mathrm{a}$ & $5132.43 \mathrm{a}$ \\
\hline 3 & 27.63 & 29.34 & 0.42 & $165.68 \mathrm{~b}$ & $4571.46 \mathrm{~b}$ \\
\hline 4 & 27.30 & 30.44 & 0.39 & $166.84 \mathrm{~b}$ & $4545.28 \mathrm{~b}$ \\
\hline 5 & 27.69 & 30.24 & 0.4 & $179.17 \mathrm{a}$ & $4958.57 \mathrm{a}$ \\
\hline $\mathrm{F}$ & $0.47^{\mathrm{ns}}$ & $2.79^{\mathrm{ns}}$ & $2.39 \mathrm{~ns}$ & $14.93 *$ & $24.70^{*}$ \\
\hline CV (\%) & 2.0 & 3.97 & 9.6 & 3.13 & 2.45 \\
\hline
\end{tabular}


Table 4 - Pearson correlation between germination (G), normal seedlings (NS), seedling dry matter (SDM), hypocotyl length (HL), root length (RL), seedling length (SL), growth index (GI), uniformity index (UI), vigor index (VI), and corrected vigor index (CVI) and the variables obtained from radiographic images in seeds and seedlings from different lots of Leucaena leucocephala.

Tabela 4 - Correlação de Pearson entre germinação $(G)$, plântulas normais (NS), matéria seca de plântulas (SDM), comprimento de hipocótilo (HL), comprimento de raiz (RL), comprimento de plântula (SL), índice de crescimento (GI), índice de uniformidade (UI), indice de vigor (VI) e indice de vigor corrigido (CVI) e as variáveis obtidas a partir de imagens radiográficas em sementes e plântulas de diferentes lotes de Leucaena leucocephala.

\begin{tabular}{lccccccccccccc}
\hline X-ray Variable & \multicolumn{8}{c}{ Physiological characterization test } \\
\cline { 2 - 10 } & $\mathrm{G}$ & $\mathrm{NS}$ & $\mathrm{SDM}$ & $\mathrm{HL}$ & $\mathrm{RL}$ & $\mathrm{SL}$ & $\mathrm{GI}$ & $\mathrm{UI}$ & $\mathrm{VI}$ & $\mathrm{CVI}$ \\
\hline Insect damage & $-0.84^{*}$ & $-0.9^{*}$ & $-0.93^{*}$ & $-0.85^{*}$ & $-0.89^{*}$ & $-0.88^{*}$ & $-0.89^{*}$ & $-0.86^{*}$ & $-0.88^{*}$ & $-0.87^{*}$ \\
Fungus damage & $0.19 \mathrm{~ns}$ & $0.25 \mathrm{~ns}$ & $0.48 \mathrm{~ns}$ & $0.19 \mathrm{~ns}$ & $0.18 \mathrm{~ns}$ & $0.17 \mathrm{~ns}$ & $0.17 \mathrm{~ns}$ & $0.13 \mathrm{~ns}$ & $0.16 \mathrm{~ns}$ & $0.16 \mathrm{~ns}$ \\
Absence of damage & $0.90^{*}$ & $0.95^{*}$ & $0.93^{*}$ & $0.9 *$ & $0.95^{*}$ & $0.94^{*}$ & $0.95^{*}$ & $0.93^{*}$ & $0.95^{*}$ & $0.93^{*}$ \\
Area & $-0.29 \mathrm{~ns}$ & $-0.24 \mathrm{~ns}$ & $0.15 \mathrm{~ns}$ & $-0.12 \mathrm{~ns}$ & $-0.15 \mathrm{~ns}$ & $-0.15 \mathrm{~ns}$ & $-0.15 \mathrm{~ns}$ & $-0.28 \mathrm{~ns}$ & $-0.17 \mathrm{~ns}$ & $-0.22 \mathrm{~ns}$ \\
Perimeter & $-0.16 \mathrm{~ns}$ & $-0.19 \mathrm{~ns}$ & $-0.31 \mathrm{~ns}$ & $-0.37^{*}$ & $-0.36 \mathrm{~ns}$ & $-0.37 \mathrm{~ns}$ & $-0.37 \mathrm{~ns}$ & $-0.26 \mathrm{~ns}$ & $-0.34 \mathrm{~ns}$ & $-0.29 \mathrm{~ns}$ \\
Circularity & $0.27 \mathrm{~ns}$ & $0.29 \mathrm{~ns}$ & $0.39 \mathrm{~ns}$ & $0.47 \mathrm{~ns}$ & $0.45 \mathrm{~ns}$ & $0.46 \mathrm{~ns}$ & $0.46 \mathrm{~ns}$ & $0.35 \mathrm{~ns}$ & $0.44 \mathrm{~ns}$ & $0.39 \mathrm{~ns}$ \\
Relative density & $0.89^{*}$ & $0.94^{*}$ & $0.93^{*}$ & $0.89^{*}$ & $0.96^{*}$ & $0.94^{*}$ & $0.95^{*}$ & $0.93^{*}$ & $0.95^{*}$ & $0.93^{*}$ \\
Integrated density & $0.86^{*}$ & $0.92^{*}$ & $0.96^{*}$ & $0.88^{*}$ & $0.94^{*}$ & $0.93^{*}$ & $0.94^{*}$ & $0.91^{*}$ & $0.93^{*}$ & $0.91^{*}$ \\
\hline
\end{tabular}

$*$, ns significant and non-significant at $5 \%$ probability by the $\mathrm{t}$ test.

*, ns é significativo e não-significativo com $5 \%$ de probabilidade pelo teste $t$.

this species (Brasil, 2008) indicating high viability of the lots. However, although the viability of the lots may be similar, vigor tends to diverge among them, taking the physiological parameters tested in this study as a basis.

The lack of differentiation among lots by the seedling dry matter test is related to the use of only normal seedlings in the test. This led to a narrowing of the differences among the lots, since in some lots a representative number of abnormal seedlings was obtained but disregarded in this evaluation. This result indicates that in the lots of L. leucocephala analyzed, the seedlings considered normal obtained a similar pattern of transfer of dry matter from reserve tissues to the embryonic axis, in spite of the vigor differences indicated by other tests (Bewley et al., 2013).

For the seedling length variable, the higher performing lots had seedlings with higher rates of development, growth, and uniformity, which was provided by the greater capacity of the seed in transferring its reserves to compose and establish development of the embryonic axis, and this was reflected in greater vigor in the seed lots (Nakagawa et al., 1999). Shorter seedling length was observed in lots 3 and 4, which may be related to this lower capacity in transferring reserves for development of the embryonic axis because the tissues have a higher degree of deterioration.

The growth, uniformity, and vigor indices defined for evaluation of seed physiological quality were efficient variables. Their application in other crops has also shown promising results in identification of vigor differences among seed lots, especially for highly cultivated species like maize (Alvarenga et al., 2012; Sena et al., 2015; Castan et al., 2018), soybean (Marcos Filho et al., 2009; Wendt et al., 2014, 2017; Medeiros and Pereira, 2018), and many others. These indices have not yet been greatly exploited for forest species; studies on Mimosa bimucronata (De Candole) Otto Kuntze (Brancalion et al., 2008) and Guazuma ulmifolia Lam. (Brancalion et al., 2010) are found in the literature.

In addition to the indices proposed by Sako et al. (2001), this study implemented use of the corrected vigorindex (Medeiros and Pereira, 2018), which proved to be the variable most sensitive to categorization of the lots, since ranking was made at four levels of vigor. The corrected vigor index integrates seedling growth and uniformity of development with germination of the lot such that there is a more coherent fit between viability and vigor (Medeiros and Pereira, 2018). This concurrence between germination and seedling length allows a more consistent evaluation of physiological quality of the seed lot (Nakagawa et al., 1999).

\subsection{Identification of seed damage}

The X-ray technique distinguished injury brought about by insect predation as the biggest cause of damage among the lots evaluated. Through $\mathrm{X}$-ray analysis, the most highly damaged lots (3 and 4) could be discriminated. The damage in these seeds was not identified by simple external visualization, and this represents a potential singularity of the X-ray

Revista Árvore 2019;43(2):e430208 
technique upon allowing visualization of inner seed morphology (Nunes et al., 2014).

Studies developed with cowpea and soybean seeds confirm the accuracy and precision of the X-ray test in identification of damage caused by insects, and its consequences on seed physiological quality. Through this technique, it was possible to determine the severity of damage both in the embryonic axis and in the cotyledons of both species, making it possible to predict which seeds would give rise to a normal or abnormal seedling (Pinto et al., 2009; Melo et al., 2010).

\subsection{Semi-automated analysis of seed X-rays}

However, when radiographic images are visually evaluated by an analyst, errors of interpretation can arise (Abud et al., 2018). In this regard, combining the X-ray technique with automated measurement tools can contribute in a significant way to seed selection, allowing highly accurate deduction of seed physiological quality from identification of the region of the seed that has been damaged.

The values of semi-automated analysis of the $\mathrm{X}$-rays regarding relative density were higher than those reported by Abud et al. (2018) in seeds of two broccoli cultivars under the $\mathrm{X}$-ray test. This difference in density may be related to factors such as adjustment of the voltage configurations and exposure time of the equipment, calibration of contrast of the image generated, and the characteristics of the species evaluated. Even so, seeds with greater relative density obtained within the same pattern of image acquisition were classified as having higher vigor that led to normal seedlings of greater length.

Differences were not found among lots for the shape descriptors generated from analysis in Image $\mathrm{J}($, thus showing homogeneity among individuals for these traits. The homogeneity found in shape and size of the L. leucocephala seeds may be due to the seeds having been obtained from mother trees near each other and from the same stratum of the plant.

Given these results, X-ray analysis through the semi-automated measurement tool allowed seeds with better physical and physiological quality to be differentiated, characterizing seeds from lots 1 and 2, in all the variables analyzed, as those that obtained the best performance, whereas seeds from lots 3 and 4 exhibited the most damage, resulting in low performance and growth.

\subsection{Pearson correlation}

In correlation analysis, the results obtained in the correlations among the shape descriptors differ from those observed by Abud et al. (2018), who indicated strong correlations of area (positive correlation) and of circularity (negative correlation) with seedling length of broccoli, Nevertheless, Abud et al. (2018) correlated these traits from categories classified according to gray density, whereas in this study, correlation between the variables was made directly with the seed lots.

Also, in correlation analysis, there was no interdependence between fungus damage and physiological characterization, since there was little representation of this type of damage among the lots $(0-6 \%)$. It is possible that fungus contamination was superficial and did not reach the internal tissues and, thus, did not damage the seeds to the point of compromising their quality. Nevertheless, a significant negative correlation of high magnitude was identified between the results of physiological characterization and of the insect damage variable among the lots $(1-25 \%)$. That indicates that seeds damaged from insect predation tend to have lower physiological quality, directly compromising vigor and, depending on the extent and location of the damage, reducing seed viability. Studies performed on soybean (Pinto et al., 2009), cowpea (Melo et al., 2010), and sorghum (Javorski and Cicero, 2017) also showed the efficiency of X-ray image analysis in evaluation and identification of insect damage, allowing it to be related to germination results and to vigor tests.

The other variables generated from X-ray images (e.g., relative density and integrated density) were highly correlated with the variables of physiological characterization, indicating high dependency among them. Other authors also found positive correlations between gray density of seed X-ray images and seedling length, suggesting use of the technique in evaluation of seed physiological potential (Abud et al., 2018).

This result indicates that the $\mathrm{X}$-ray technique is efficient in estimating seed viability and vigor from the relative density and integrated density variables 
obtained in analysis of seed X-ray images, which represents an important contribution in adaptation of the method using semi-automated measurement tools.

\section{CONCLUSIONS}

Semi-automated analysis associated with analysis of seed images obtained in the X-ray test is efficient in evaluating the inner morphology of Leucaena leucocephala seeds. Relative density and integrated density are related to physiological quality, which allows seed lots to be classified for vigor. In addition, the X-ray test is suitable for identifying damage in seeds and allows the cause of vigor loss to be identified when this loss is brought about by insects.

\section{REFERENCES}

Abud HF, Cicero SM, Gomes Junior FG.

Radiographic images and relationship of the internal morphology and physiological potential of broccoli seeds. Acta Scientiarum: Agronomy. 2018;40(1):1-9.

Alvarenga RO, Marcos-Filho J, Gomes Junior FG. Avaliação do vigor de sementes de milho superdoce por meio da análise computadorizada de imagens de plântulas. Revista Brasileira Sementes. 2012;34(3):488-494.

Bewley JD, Bradford K, Hilhorst H, Nonogaki H. Seeds: physiology of development, germination and dormancy. 3 rd. New York: Springer; 2013.

Brancalion PHS, Novembre ADLC, Rodrigues RR, Tay D. Priming of Mimosa bimucronata Seeds - A Tropical Tree Species from Brazil. Acta Horticulturae. 2008;782:163-168.

Brancalion PHS, Tay D, Novembre ADLC, Rodrigues RR, Marcos-Filho J. Priming of pioneer tree Guazuma ulmifolia (Malvaceae) seeds evaluated by an automated computer image analysis. Scientia Agricola. 2010;67(3):274-279.

Brasil. Ministério da Agricultura, Pecuária e Abastecimento. Regras para análise de sementes. Brasília, DF: MAPA/ACS; 2009.

Brasil. Ministério da Agricultura, Pecuária e Abastecimento. Normas e padrões para comercialização de sementes de espécies forrageiras de clima tropical. Brasília, DF: Diário Oficial da República Federativa do Brasil; 2008.

Castan DOC, Gomes-Junior FG, Marcos-Filho J. Vigor S, a new system for evaluating the physiological potential of maize seeds. Scientia Agricola. 2018;75(2):167-172.

Yige C, Fangqing C, Lei L, Shunbo Z. Physiological responses of Leucaena leucocephala seedlings to drought stress. Procedia Engineering. 2012;28:110-116.

Geiger M, Blem G, Ludwig A. Evaluation of ImageJ for relative bone density measurement and clinical application. Journal of Oral Health and Craniofacial Science. 2016;1(1):012-021.

Gomes KBP, Martins RCC, Martins IS, Gomes Junior FG. Avaliação da morfologia interna de sementes de Terminalia argentea (Combretaceae) pelo teste de raios X. Revista Ciência Agronômica. 2014;45(4):752-759.

Honda MDH, Ishihara KL, Pham DT, Borthakur D. Identification of drought-induced genes in giant leucaena ( Leucaena leucocephala subsp. glabrata). Trees. 2018;32(2):571-585.

Javorski M, Cicero SM. Utilização do teste de raios X na avaliação da qualidade de sementes de sorgo. Revista Brasileira de Milho e Sorgo. 2017;16(2):310-318.

Krzyananowski FC, Vieira RD, França-Neto JB. Vigor de sementes: conceitos e testes. Londrina (PR): Abrates: 1999.

Marchi JL, Cicero SM. Use of the software Seed Vigor Imaging System (SVIS $®$ ) for assessing vigor of carrot seeds. Scientia Agricola. 2017;74(6):469-473.

Marchi JL, Gomes Junior FG. Use of image analysis techniques to determine the embryo size of Senna multijuga (Rich.) seeds and its relation to germination and vigor. Journal of Seed Science. 2017;39(1):13-19.

Marcos-Filho J. Seed Physiology of Cultivated Plants. Londrina (PR): Abrates; 2016.

Marcos Filho J, Kikuti ALP, Lima LB. Métodos para

Revista Árvore 2019;43(2):e430208 
avaliação do vigor de sementes de soja, incluindo a análise computadorizada de imagens. Revista Brasileira de Sementes. 2009;31(1):102-112.

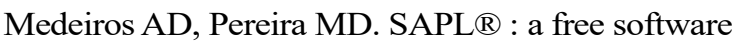
for determining the physiological potential in soybean seeds. Pesquisa Agropecuária Tropical. 2018;48(3):222-228.

Melo RA, Forti VA, Cicero SM, Novembre ADLC, Melo PCT. Use of X-ray to evaluate damage caused by weevils in cowpea seeds. Horticultura Brasileira. 2010;28(4):472-476.

Nakagawa J, Krzyzanowski FC, Vieira RD, França Neto JB. Testes de vigor baseados no desempenho das plântulas. In: Krzyananowski FC, Vieira RD, França-Neto JB. Vigor de sementes: conceitos e testes. Londrina, PR: Abrates; 1999. p. 9-13.

Noronha BG, Medeiros AD, Pereira MD. Avaliação da qualidade fisiológica de sementes de Moringa oleifera Lam. Ciência Florestal. 2018;28(1):393-402.

Nunes RTC, Souza UO, Morais OM, Lourenço CMS. Análise de imagens na avaliação da qualidade fisiológica de sementes. Revista Verde de Agroecologia e Desenvolvimento Sustentável. 2014;9(5):84-90.

Pereyra G, Hartmann H, Michalzik B, Ziegler W, Trumbore SE. Influence of rhizobia inoculation on biomass gain and tissue nitrogen content of Leucaena leucocephala seedlings under drought. Forests. 2015;6(10):3686-3703.

Pinto TLF, Cicero SM, França-Neto JB, Forti VA. An assessment of mechanical and stink bug damage in soybean seed using X-ray analysis test. Seed Science and Technology. 2009;37(1):110-120.
Prado AMV, Von Pinho ÉVR, Santos HO, Prado AGC, Carvalho MLM, Bustamante FO. Image analysis, quality and maturation of jiló (Solanum gilo) seeds. Agrociencia. 2018;52(2):267-278.

R Core Team. R Development Core Team. R: A Language and Environment for Statistical Computing. 2017.

Sako Y, Mcdonald MB, Fujimura K, Evans AF, Bennett MA. A system for automated seed vigour assessment. Seed Science and Technology. $2001 ; 29(3): 625-636$.

Schneider CA, Rasband WS, Eliceiri KW. NIH Image to ImageJ: 25 years of image analysis. Nature Methods. 2012;9(7):671-675.

Sena DVA, Alves EU, Medeiros DS. Vigor de sementes de milho cv. 'Sertanejo' por testes baseados no desempenho de plântulas. Ciência Rural. 2015;45(11):1910-1916.

Silva VN, Sarmento MB, Silveira AC, Silva CS, Cicero SM. Avaliação da morfologia interna de sementes de Acca sellowiana $\mathrm{O}$. Berg por meio de análise de imagens. Revista Brasileira de Fruticultura. 2013;35(4):1158-1169.

Wendt L, Gomes Junior FG, Zorato MF, Moreira GC. Avaliação do potencial fisiológico de sementes de soja por meio de imagens. Pesquisa Agropecuária Tropical. 2014;44(3):280-286.

Wendt L, Malavasi MM, Dranski JAL, Malavasi UC, Gomes Junior FG. Relação entre testes de vigor com a emergência a campo em sementes de soja. Brazilian Journal of Agricultural Sciences. 2017;12(2):166-171. 